\title{
MOZAIKOKBÓL EGYÉLET
}

A címadás kifejezi a könyv jellegét, szerkesztésmódját. Benne van a szerző, Hargittai István tudós életútjának megannyi jelentős fordulata, meghatározó találkozása. A kötetnek akár alcíme is lehetne: Portrévázlatok és találkozások. Visszatekintve a pályára az emlékek elevensége, mélysége, részletessége sokat elárul egy-egy találkozás jelentőségéről. Ez a szerkesztésmód vállalható akkor is, ha valaki kifejezetten memoárt, emlékiratot ír, és többé-kevésbé időrendben halad. A sokkönyvü szerző ugyanis nem időrendben, hanem a portrékban megidézett. közel félszáz személy nevének ábécérendjében beszéli el fontosnak ítélt találkozásait. Természetesen a beválogatott portrévázlatokból nem áll össze a szerző életének teljes képe, de kiviláglik a pálya sok fényes, sikeres napja, számtalan jelentős találkozása a kor nagy tudósaival, neves személyiségeivel. Jogosan írja az utószóban, hogy „Az említett és a bennem maradó nevek, személyek révén hihetetlen gazdagságot érzek, hálát és elégedettséget”.

A portrék, a mozaikok azok esetében is fontos üzenetet közvetítenek, akikről Hargittai Istvánnak korábban már önálló kötete jelent meg (például Teller Ede), vagy akikről gyüjteményes kötetben szólt (például Furka Árpád). Olyan erős emberekről olvashatunk a könyvben, akik örök példaként állíthatók az ifjúság elé. Az Oláh Györgyről szóló mozaik mottója „Tragédiákból a csúcsra” ilyen példára utal. Róla kevesen tudják (a magyar Nobel-díjasokat számlálgatók között is), hogy a vészkorszakot Sztehlo Gábor evangélikus lelkész védő szárnyai alatt élte túl! A „mozaikok” tele van váratlan, elejtett információkkal, neves, nagy tudósok származásának vonatkozásaival. A Richard Garwinról szóló, Magyar tudósok lehettek volna alcímmel jelzett mozaikból derült ki számomra Richard L. Garwin, Robert F. Furchgott, Charles Weissmann, George Radda, Peter Lax gyökereinek magyar (magyarországi) vonatkozása. Mintegy véletlenül, a Fejes Tóth Lászlóról szóló megemlékezésben olvashatunk Erdős Pálról, a legendás utazó matematikusról, aki önálló portrét is megérdemelne.

Ez a könyv a magyar tudományosság számára azért is nagy jelentőségủ mü, mert sok magyar származású és „magyarnak számkivetett” tudós életútjáról ad hiteles és érdekfeszítő, személyes találkozáson összegyüjtött információkat. Ez a személyesség, a találkozások varázsa teszi ezt a mozaikos történetfolyamot igazán érdekessé, élményszerủvé az olvasó számára. Páratlan teljesítmény annyi jelentős tudóssal személyes kontaktusba kerülni és róluk hitelesen, jól dokumentáltan szólni. A Hargittai Istvánéhoz hasonló tudománytörténeti és tudománynépszerüsítő életművet én nem ismerek. Nem véletlen, hogy müveinek java angolul is megjelent, olykor előbb, mint a magyar változat. Hargittai hihetetlen energiá- 
val kereste és dokumentálta a találkozásokat, élt a véletlen hozta lehetőségekkel. A Bevezetésben olvashatjuk, hogy „,a több száz meginterjúvolt tudós között legalább száz Nobel-díjas volt". Nincs róla biztos tudomásom, de azt gyanítom, hogy ez a szám a maga nemében „világcsúcsnak” vehető.

A kötetben, mint Hargittai számos, más tudománytörténeti munkájában, kitüntetett szerepet kapnak a Magyarországról elszármazott tudósok. Rokonszenvvel ír Marx György tevékenységéröl, aki visszahozta a köztudatba az antiszemitizmus miatt emigrált nagy tudósokat, s aki megszervezte Wigner Jenő látogatását Magyarországra, Teller Edét pedig 1989-ben az MTA tiszteleti tagságára ajánlotta. Az öt „marslakó” (Kármán Tódor, Neumann János, Szilárd Leó, Teller Ede és Wigner Jenő) jelentőségét a 20. század tudományos-technikai haladásában aligha lehet túlbecsülni. A Wigner Jenőröl szóló „mozaik” nem csupán a szerző személyes emlékeit ismerteti kettejük 1969-ben történt megismerkedéséről és beszélgetéseiről, hanem a Nobel-díjas tudós Magyarországhoz, a magyar irodalomhoz füződő érzelmeiröl is értékes adalékokat közöl. (Megtudható belőle, hogy Wigner kedves költője Vörösmarty volt, és szerette Radnóti verseit!)

Etnográfusként nagyra értékelem, hogy a tudósi kiválóság mellett az emberi minőségre is érzékenyen választotta meg beszélgetőpartnereit, válogatta össze a kötetbe került portrékat. Szeretettel ír egykori tanáráról (Csonkás Mihály), az MTA Kémiai Kutatólaborjának zseniális mühelyfőnökéről (Hernádi József) és a szimmetriakutatások során megismert müvészekről (Lantos Ferenc, Orosz István), sőt a magyar népi hímzések kiváló kutatójáról (Lengyel Györgyi) is.

Itt-ott elszórtan olvashatunk a könyvben a szerző életútjának válságos, olykor kilátástalan, embert próbáló szakaszairól. Ezek döntően a II. világháború éveihez, a vészkorszakhoz kapcsolódtak, de jutott belölük az osztályharcos pártállami évtizedekre is. Csecsemőkorában veszítette el aknaszedésre kirendelt munkaszolgálatos apját. 1944-ben egy tévedésnek volt köszönhető, hogy marhavagonokból álló szerelvényüket Auschwitz helyett Ausztriába irányították. A világháborút követően „osztályidegen származású” gyerekként a budapesti lakás elvesztését élte meg anyjával és bátyjával, $\mathrm{s}$ ismét az orosházi anyai nagyszülőknél talált időleges menedéket. Rögös út vezetett az orosházi elemi iskolától az egyetemig, az Ortutay Gyula rektori keretéből történt egyetemi felvételig. Meg kellett küzdenie azért, hogy egyáltalán továbbtanulhasson és tandíjat fizethessen. Sorsa akkor fordult jobbra, amikor az 1960-as években a moszkvai Lomonoszov Egyetemen folytathatta tanulmányait.

A könyv bevezetésében küzdelmes gyermek- és ifjúkoráról írja: „Pályám és egész életem során sokszor hajszálon múlt, hogy egyröl a kettőre jutottam. Ha egyetlen tényezőt kell kiemelnem, mint szerencsés körülményt, akkor az emberi kapcsolatokat említeném. Egy középiskolai matematikatanár, egy moszkvai professzor, egy norvég akadémikus, egy mechanikai műszerész, egy könyvsorozat 
szerkesztője, egy impresszionista festő képe, egy lapkiadó - mind-mind hoszszabb-rövidebb ideig pozitívan befolyásolta pályámat."

Hargittai István szép magyarsággal, olvasmányosan ír. Könyve - az akadémiai szférán túlmenően - széles olvasóközönségre számíthat. Ott lenne a helye minden közép- és főiskolai könyvtárban és az egész magyar könyvtári hálózatban.

(Hargittai István: Mozaikokból egy élet. Budapest: Akadémiai Kiadó, 2019, 254 o.)

Paládi-Kovács Attila az MTA rendes tagja, professor emeritus 